\title{
NOTE
}

\section{Effect of Methallibure (ICI Compound, 33, 828) on Ovarian Activity in the Catfish, Heteropneustes fossilis (Bloch)}

\author{
R. B. RAIZADA* AND T. P. SINGH \\ Department of Zoology, Banaras Hindu University, \\ Varanasi-221005, India
}

\begin{abstract}
Synopsis
The effect of methallibure on ovary of $H$. fossilis was studied. Intraperitoneal administration of methalibure $(100 \mu \mathrm{g} / \mathrm{g}$ body weight) once a week for 4 weeks was very effective in suppressing the gametogenic and endocrine activities of ovary. The regressed condition of ovary was also apparent in GSI (2.84 to 1.09$)$ readings. This decreased state of activity was further confirmed by reduced ovarian ${ }^{32} \mathrm{P}$ uptake $(28.00$ to 18.10$)$. The results obtained after the administration of the above compound on ovary were similar to those of surgical hypophysectomy.
\end{abstract}

Several methods are known to demonstrate the pituitary regulation of gonadal function in vertebrates. The most convincing of all is the hypophysectomy and replacement therapy, though the removal of hypophysis deprives animal not only of gonadotrophins but also from other trophic hormones. Chemical inhibition of pituitary gonadotrophins can be achieved by many known compounds but most of them are steroids which interfere in the feedback pathways. Use of nonsteroidal and nonhormonal chemical inhibition of pituitary gonadotropic activity by methallibure (a derivative of dithiocarbamoyal hydrazine, Paget et al., 1961) was a clear breakthrough in the study of reciprocal physiological relationship between pituitary and gonads. In teleost effect of ICI compound 33,828

\footnotetext{
Received for publication July 6, 1976.

Mailing Address: Dr. T. P. Singh, Department of Zoology, Banaras Hindu University, Varanasi-221005, India.

* Present Address: Pesticide Division, Industrial Toxicology Research Center, P.O.Box-80, Lucknow, INDIA
}

(methallibure) was first investigated by Hoar et al. 1967. They have suggested that the effect of methallibure "is a direct one on the synthesis, release and action of gonadotropins". The use of this compound in the place of surgical hypophysectomy has been advocated by some workers (Wiebe, 1968; Leatherland, 1969; Pandey and Leatherland, 1970; Mackay, 1973; Raizada and Singh, 1973) over gonadal activity.

This investigation was undertaken to study the effect of methallibure on ovary as an alternative to hypophysectomy in Heteropneustes fossilis. This species was specially selected because hypophysectomy is very difficult and cumbersome in this species and mortality in operated specimens is also very high. Besides being very important food fish this species makes also a very suitable experimental material because it is very hardy and demonstrated unusual tolerance for operation and injection strains. 


\section{Materials and Methods}

Thirty-five adult females of the fresh water catfish, $H$. fossilis with an average weight of $32.0 \mathrm{~g}$. and length of $17.0 \mathrm{~cm}$. utilized in this experiment were collected from ponds around Varanasi (India). They were kept under laboratory condition for a fortnight prior to the experimentation. The fish were fed with commercial fish food and liver ad libitum. The experiment was performed in the month of July. Temperature of aquarium water was not controlled, however, variations were similar in all aquariums and ranged from 22 to $26^{\circ} \mathrm{C}$. Specimens were equally divided into 7 batches containing 5 individuals in each. At the initial phase of experiment 5 fish of batch 1 were given a tracer shot of ${ }^{32} \mathrm{P}(5 \mu \mathrm{Ci} /$ fish $)$ and killed 12 hours after the injection for estimating GSI, ova diameter and radiophosphorous uptake. The remaining specimens were subjected to various treatments. The details of treatment, dosages and time interval are given in the table. All injections were given intraperitoneally unless mentioned otherwise. Before injection fish were anaesthetized with MS 222 (Tricane methane sulfonate-generously gifted by Sanxoz Ltd., Switzerland through the kind courtesy of Drs. Taeschler and Friedle). Immediately after the last injection specimens of all batches were given a tracer dose of ${ }^{32} \mathrm{P}$ individually and sacrificed 12 hours later after recording their weight. Weight of ovaries of each specimen were recorded along with its body weight and measured samples from the middle portion of each ovary were taken for estimation of ${ }^{32} \mathbf{P}$ uptake. Uptake is expressed in the term of maximum percentage of ${ }^{32} \mathbf{P}$ incorporation by unit weight of ovary in relation to the total injected dose after 12 hours of radioisotope injection. Calculations were made after taking into account the necessary decay corrections of ${ }^{32} \mathbf{P}$. Samples from individual ovary were also fixed in Bouin's fluid for histological studies and ova diameter measurements. Diameter of ova in a batch represents the mean of means of diameter records in five fish. Average diameter of ova in a fish was recorded by measuring, 10 different ova in that fish. The mean was taken for a batch from the mean readings of five fish comprising the batch. The following equation (Singh, 1970) was used for calculation of GSI values: GSI = (weight of ovary/body weight) $\times 100$.

\section{Results}

July and August were the months of vigorous ovarian activity in $H$. fossilis, when maximum growth and maturation of ova were observed. At the onset of this experiment in early July fish were in prespawning phase with distinct growth and differentiation of large number of ova, with plenty of yolk in some of them. The GSI was 2.84 and the ova diameter at the onset of experiment was $760 \mu \mathrm{m}$. The methallibure treatment at the dose level of $100 \mu \mathrm{g}$ per gram body weight given once a week for four weeks through intraperitoneal injections appeared to be very effective not in suppressing the growth and maturation of ovary but also induced gradual regression and atrophy. The GSI was reduced to 1.09 from 2.84 whereas the GSI in untreated control had increased to 3.10 due to progressive maturation (Table 1). Average maximum measurements of ova diameter recorded a downtrend and measured $400 \mu \mathrm{m}$. The percentage radiophosphorus uptake by the ovary in methallibure-treated group was also reduced to 18.10 as compared to controls 28.00. Hypophysectomized individuals registered a significant reduction in the ovarian activity by all parameters (Table 1, batch 3).

Ovarian activity in the specimens of batch 4 recorded lower values even after methallibure injection was coupled with $\mathrm{LH}$ at the dose level of $100 \mu \mathrm{g} /$ fish. But hypophysectomized fish given $\mathrm{LH}$ injection (100 $\mu \mathrm{g} /$ fish) demonstrated hightend ovarian activity (Table 1, batch 5). In hypophysectomized specimens treated with methallibure and $\mathrm{LH}$ the rate of reduction in ovarian activity was similar to the hypophysectomized batch getting no treatment (batch 6).

Histology of ovary revealed general trend of atrophy and degeneration of large oocytes in methallibure treated and hypophysectomized groups. These data have been communicated elsewhere for publication. Normal picture of ovary was apparent in hypophysectomized specimens getting LH injections (batch 5). Ovarian 
Table 1. GSI, ova diameter and ${ }^{32} \mathrm{P}$ uptake after methallibure treatment in $H$. fossilis

\begin{tabular}{|c|c|c|c|c|}
\hline Batch* & Treatment, dosage and frequency & $\begin{array}{c}\text { GSI } \\
\text { Mean } \pm \text { S.E.M. }\end{array}$ & $\begin{array}{l}\text { Ova diamer in } \mu \mathrm{m} \\
\text { Mean } \pm \text { S.E.M. }\end{array}$ & $\begin{array}{l}\text { 32P uptake per } g \\
\text { of ovary(c) } \\
\text { Mean } \pm \text { S.E.M. }\end{array}$ \\
\hline 1 & Start of Experiment & $2.84 \pm 0.35$ & $760.00 \pm 78.00$ & $23.00 \pm 2.35$ \\
\hline 2 & $\begin{array}{l}\text { Methallibure } 100 \mu \mathrm{g} / \mathrm{g} \text { of body weight, } \\
\text { given once a week for } 4 \text { weeks }\end{array}$ & $\begin{array}{l}1.09 \pm 0.42 \\
(P<0.05)\end{array}$ & $\begin{array}{l}410.00 \pm 32.00 \\
\quad(P<0.05)\end{array}$ & $\begin{array}{l}18.10 \pm 2.18 \\
(P<0.05)\end{array}$ \\
\hline 3 & Hypophysectomized & $\begin{array}{l}0.74 \pm 0.26 \\
(P<0.01)\end{array}$ & $\begin{array}{l}320.00 \pm 54.00 \\
\quad(P<0.01)\end{array}$ & $\begin{array}{c}10.90 \pm 1.70 \\
(P<0.02)\end{array}$ \\
\hline 4 & $\begin{array}{l}\text { Methallibure } 100 \mu \mathrm{g} / \mathrm{g}+\mathrm{LH} \quad 100 \mu \mathrm{g} / \\
\text { fish once a week for } 4 \text { weeks }\end{array}$ & $\begin{array}{l}1.37 \pm 0.57 \\
(\mathrm{P}<0.05)\end{array}$ & $\begin{array}{l}466.00 \pm 70.00 \\
\quad(P<0.05)\end{array}$ & $\begin{array}{l}19.10 \pm 3.00 \\
(\mathrm{P}<0.05)\end{array}$ \\
\hline 5 & $\begin{array}{l}\text { Hypophysectomized }+\mathrm{LH} 100 \mu \mathrm{g} / \text { fish } \\
\text { once a week for } 4 \text { weeks }\end{array}$ & $\begin{array}{l}4.00 \pm 0.38 \\
\text { N.S. }\end{array}$ & $\begin{array}{l}800.00 \pm 88.00 \\
\text { N. S. }\end{array}$ & $\begin{array}{l}30.25 \pm 3.50 \\
\text { N. S. }\end{array}$ \\
\hline 6 & $\begin{array}{l}\text { Hypophysectomized }+ \text { Methallibure }+ \\
\text { LH at the above dose level, once a } \\
\text { week for } 4 \text { weeks }\end{array}$ & $\begin{array}{l}0.88 \pm 0.24 \\
(\mathrm{P}<0.01)\end{array}$ & $\begin{array}{l}324.00 \pm 77.00 \\
\quad(\mathrm{P}<0.01)\end{array}$ & $\begin{array}{c}11.37 \pm 1.66 \\
(\mathrm{P}<0.03)\end{array}$ \\
\hline 7 & $\begin{array}{l}\text { Control given } 0.6 \% \text { saline injection } \\
\text { for same time and interval }\end{array}$ & $3.10 \pm 0.29$ & $790.00 \pm 64.00$ & $28.00 \pm 4.30$ \\
\hline
\end{tabular}

* Each batch had 5 specimens, $\mathrm{P}$ values for different parameters given in parentheses are against control batch 7 .

(a) maximum percentage of ${ }^{32} \mathrm{P}$ uptake in relation to the total injected dose.

Ovine LH of NIH -LH -S19 lot with specific activity of 1.01 USP units/mg.

atrophy in batches 4 and 6 was similar to those recorded in hypophysectomized and methallibure administered groups (batches 2 and 3 ).

\section{Discussion}

Reduction in gonadosomatic index within four weeks after methallibure administration was very well marked in females of H. fossilis. This observation of decreased gonadosomatic index was similar to those reported by Hoar et al. 1967; Wiebe, 1968 ; Pandey and Leatherland, 1969. This regressed phase of ovarian activity as reflected by an appreciable decrease in GSI and in histological pictures was further confirmed by radiophosphorus uptake of ovary which is more sensitive and reliable parameter for the evaluation of ovarian activity. Hoar et al., 1967; Wiebe, 1968 ; Pandey and Leatherland, 1970 have suggested that methallibure is a chemical which inhibits the action of gonadotropins on gonads and hence prevent the maturation and steroidogenesis. The above workers, however, were not certain on the mode of action of methallibure on pituitary whether the blocking was due to the failure of synthesis of gonadotropins or failure in their release or both.

In H. fossilis methallibure blocks the action of exogenously administered LH. Injection of LH has also failed to restore ovarian activity in hypophysectomized individuals if given along with methallibure. Serum and pituitary glands were assayed for estimation of their gonadotropin contents in methallibure treated specimens and results showed that this drug prevented the secretion of gonadotropins and also blocked the action of internal as well as of peripheral gonadotropins on ovary (Singh et al., 1977).

It is apparent from the finding of this experiment that the methallibure prevents the action of gonadotropins on ovary and ovarian atrophy induced is similar to the one resulting after hypophysectomy. 


\section{Acknowledgement}

The authors are grateful to Professor J. P. Thapliyal, Department of Zoology for providing the necessary facilities. The authors wish to thank Dr. E. R. S. Talpasayi, Department of Botany for allowing the use of Scintillation Counter under his charge. We are thankful for the generous supply of LH and methallibure to Dr. R. W. Bates of NIH, U.S.A. and to Dr. R. A. Wilkkinson of ICI Ltd., U. K., respectively. Financial assistance for the project in the form of Senior Research Fellowship was provided to one of us (RBR) from Indian Council of Agricultural Research, New Delhi, India.

\section{References}

Hoar, W. S., J. Wiebe and E. Huewai (1967). Gen. Comp. Endocrinology 8, 101.

Leatherland, J. F. (1969). Z. Zellforsch. 98, 122.

Mackay, N. J. (1973). Gen. Comp. Endocrinol. 20, 221.

Paget, G. E., A. L. Walpole and D. N. Richardson (1961). Nature, London, 192, 191.

Pandey, S. and J. F. Leatherland (1970). Can. J. Zool., 48, 445.

Raizada, R. B. and T. P. Singh (1973). Rec. Prog. Comp. Endocrinol. Symp. Chandigarh, pp. 12.

Singh, T. P. (1970). Endocrinologie 56, 292.

Singh, T. P., R. B. Raizada and A. K. Singh (1977). J. Endocrinol. 72, 321.

Wiebe, J. P. (1968). Can. J. Zool., 46, 751. 